\title{
Effect of Storage Conditions on the Sugar Recovery, Sucrose Loss in Wastes and Juice Purity during Sugar Beet Manufacture
}

\author{
Mokhless A. M. Abd El-Rahman; Safaa A. Limam; Mennat-Allah M. A. El-Geddawy \\ Food Sci. \& Tech. Dept., Fac. of Agric., Assiut Univ., Assiut, Egypt.
}

Received: $15 / 11 / 2019$

\begin{abstract}
Objective of this work was carried to extend shelf life of sugar beet roots by applying different conditions of storage to increase juice purity, sugar recovery and decrease sugar loss in wastes. This investigation was carried out to study the effect of three different storage procedures of four different sugar beet roots varieties (cultivars: Pleno, Top, Kawemira and Ceres poly) harvested at different periods (180, 195 and 210 days) at $12-33.60^{\circ}$ Con the white sugar production, the amount of sucrose loss in the final wastes and the purity of sugar beet juice. Ceres poly variety had the highest white sucrose recovery under the covering storage procedures ranged from 13.75 to $17.92 \%$. However, Pleno variety was the highest sucrose loss at almost harvesting days, while, Ceres poly recorded the lowest percentages in wastes at almost harvesting days. Top variety was the highest juice purity during manufacture especially at 180 and 210 days under the covering (78.27 and $84.74 \%$ ) and open-air storage (83.86 and $84.85 \%)$. All results obtained in this investigation are affected by certain factors such as sucrose, $\mathrm{K}$ and $\alpha-\mathrm{N}$ content in sugar beet roots, and the purity of sugar beet juice stored in the storage room was relatively higher compared to other treatments.
\end{abstract}

Keywords: Beta vulgaris L.; sugar recovery; sucrose loss and juice purity

\section{INTRODUCTION}

Sugar beet (Beta vulgaris L.) is the second crop for sugar production in Egypt (Mekdad, 2015). Recently, sugar beet crop has been favorable importance in local crop rotation as a winter crop. Sugar beet is becoming a growing of sugar production. It represents about $22 \%$ of Egypt total sugar production in $1999 / 2000$, compared to $20 \%$ in $1998 / 1999$. Beet sugar production in Egypt elevated from 374400 to 456000 ton in 1999 and 2000; respectively (Abou-Salama and El-Syiad, 2000). The importance of sugar beet in agriculture is not only confined to sugar production, but also to produce secondary productions (Cooke and Scott, 2012). World sugar production increased from about 10 million tons to 181 million tons from 2008/2009 to 2018/2019 (USDA, 2019; Statista, 2019).

Sugar beet has a crucial importance in human nutrition and raw material of sugar (Mustafa, 2003). The industrial demand for sugar beet is increasing, which provides a higher price, incentivizing many farmers to plant more beets. Increased sugar beet area harvested in 2019/2020 to 250,000 ha. Beets are planted in August and September and harvested in March and April. Sugar concentration in beet is $13-18 \%$ higher than $11 \%$ in sugar cane (Draycott, 2006). Egypt occupied the eighteen globally in the sugar beet production with 13323369 tons in 2018 (FAOSTAT, 2018).

In most sugar beet growing areas, harvest periods are short and in consequence sugar beet roots storage is necessary. The main faced issues of beet roots storage are quality deterioration and decline of sucrose which occurred due to respiration and activation of some enzymes, resulting in a decrease of physical and technological characteristics of sugar beet roots. Sugar yield and quality formation are a very complicated process involving a lot of factors (Pačuta et al. 2017, 2018). Pavlů et al. (2017) reported that prolongation of the vegetation period in spring to 13 days caused increasing in sugar beet root yield by $10.9 \%$.
Sugar beet roots may be stored up to 160 days, allowing weather (primarily temperature and moisture) and microbes to negativity influence the sucrose stored in the roots, along with normal respiration and the build up of impurities (Strausbaugh and Eujayl, 2009). Other factors can be also influenced sucrose loss such as unusually high or low temperatures (Draycott, 2006).

Fugate and Campbell (2009) mentioned that sugar loss in beet sugar industry occurred due to three different reasons. The first one is spoilage by microorganisms which use up sugar in respiration and produced enzymes which convert sucrose to invert sugar. The second substantial source of sugar loss occurred through direct respiration of stored beet roots. The sugar loss by direct respiration was estimated at up to 0.5 pound of sugar per ton beets per day, the last source of sugar loss is the biochemical transformation of sucrose into invert sugars which inhibited crystallization and canes difficulties in beet sugar processing. Among the three approaches causing sugar loss in beets, biochemical transformation that have received the least attention.

During the 2019/2020 season, refined sugar production is expected to increase by about $14 \%$ to 2.74 million tons, compared to the 2018/2017 estimated of 2.40 million tons. Of these total projections, 1.5 million tons of sugar beet will be produced, while 1.2 million tons will be sourced from sugarcane. With the creation of a new online processing facility and farmers' expansion of cultivated areas to meet the high consumption demand, beet sugar production in $2019 / 2020$ is expected to arise by 195,000 tons, to 1.5 million tons. This is up $15 \%$ from 1.3 million tons in the previous marketing year (USDA, 2019).

The objective of this work was carried to extend shelf life of sugar beet roots by applying different conditions of storage to increase juice purity, sugar recovery and sugar loss in wastes. 


\section{MATERIALS AND METHODS}

\section{Materials:}

Sugar beet roots (Beta vulgaris L.) cultivars: Pleno, Top, Kawemira and Ceres poly were obtained for the preliminary investigation during 2018/2019 from the fields of experiments at Sakha Research station Kafr ElSheikh Governorate Egypt. Samples of sugar beet roots of the four cultivars were individually divided into three groups (250 roots for each group) and stored for 30 days under different conditions as follows:

- The first group stored without top (but covered with its top) in open-air.

- The second group stored without top (without covering) in open-air.

- The third group stored without tops in normal store room.

The storage conditions of the stored sugar beet varieties investigated were in Table (1) as follows:

Table (1): The storage conditions of the stored sugar beet varieties

\begin{tabular}{ccc}
\hline $\begin{array}{c}\text { Harvesting } \\
\text { period }\end{array}$ & $\begin{array}{c}\text { Temperature } \\
\text { range }\end{array}$ & $\begin{array}{c}\text { Relative } \\
\text { humidity range }\end{array}$ \\
\hline $\mathbf{1 8 0}$ days & $12-27.6^{\circ} \mathrm{C}$ & $42-84 \%$ \\
$\mathbf{1 9 5}$ days & $18.5-33.6^{\circ} \mathrm{C}$ & $44-90 \%$ \\
$\mathbf{2 1 0}$ days & $22-31.8^{\circ} \mathrm{C}$ & $63-94.5 \%$ \\
\hline
\end{tabular}

The analysis was conducted at 1, 10,20 and 30 days of stored period

\section{Methods of Analysis:}

\section{Chemical composition:}

Total soluble solids (TSS) in the fresh roots were determined by hand refractometer using Carl Zeiss Jena DDR783295 (AOAC, 2012). Sucrose percentage was determined using Saccharometer on a lead basis according to the procedure of Delta Sugar Company (Le Docte, 1977). Alpha amino nitrogen, sodium and potassium they were determined according to the procedure of Delta sugar Co. using Autoanalyzer type ZIG venma, Automation BV Analyzer IIG-16-12-99, 9716JP/ Groningen/Holland. Temp. $18-30^{\circ} \mathrm{C}$, surrounding humidity max. $70 \%$ according to Brown and Lillan (1964). The results calculated as milli equivalents $/ 100 \mathrm{gm}$ beet.

\section{Determination of sugar recovery (SR) (White sugar):}

Sugar recovery percentage (SR\%) was determined according to the procedure of Delta sugar company described by Silin and Silina (1977) and Sapronova et al. (1979).

\section{Sugar losses in wastes and purity:}

Sugar losses (D) in wastes percentage and purity were determined according to the procedure of Delta Sugar Company described by Silin and Silina (1977) and Sapronova et al. (1979).

\section{RESULTS AND DISCUSSION}

\section{Sucrose recovery percentage (white sucrose):}

White sucrose percentage in sugar yield of four varieties at harvest times as influenced by periods and method of storage are presented in Tables (2, 3 and 4). Under covering storage condition Table (2) ceres poly variety recorded the highest mean values of white sucrose were ranged from 13.75 to $17.92 \%$ at all harvesting times, while, pleno variety recorded the lowest mean values at 210 days in white sucrose, however, Kawemira variety recorded the lowest mean values at 180 and 195 days were 12.33 and $13.58 \%$; respectively.

Table (2): Effect of storage period under covering storage condition on the sugar recovery percentage (white sucrose) of four sugar beet varieties harvested at different times

\begin{tabular}{cccccc}
\hline \multirow{3}{*}{ Harvesting time } & $\begin{array}{c}\text { Covering storage } \\
\text { periods in days }\end{array}$ & \multicolumn{4}{c}{ Sugar recovery \% (white sucrose) } \\
\cline { 3 - 6 } & & \multicolumn{4}{c}{ Beet varieties } \\
\cline { 3 - 6 } & $\mathbf{1}$ & 11.42 & 9.45 & 10.36 & Cleno \\
\cline { 3 - 6 } $\mathbf{1 8 0}$ days & $\mathbf{1 0}$ & 11.90 & 12.40 & 11.67 & 13.02 \\
& $\mathbf{2 0}$ & 12.94 & 13.40 & 13.60 & 16.50 \\
& $\mathbf{3 0}$ & 13.40 & 16.00 & 13.71 & 16.73 \\
\hline Mean & --- & $\mathbf{1 2 . 4 1}$ & $\mathbf{1 2 . 8 6}$ & $\mathbf{1 2 . 3 3}$ & $\mathbf{1 3 . 7 5}$ \\
\hline & $\mathbf{1}$ & 12.34 & 13.69 & 12.84 & 14.86 \\
$\mathbf{1 9 5}$ days & $\mathbf{1 0}$ & 13.31 & 13.68 & 13.21 & 16.49 \\
& $\mathbf{2 0}$ & 14.43 & 14.70 & 14.17 & 17.22 \\
& $\mathbf{3 0}$ & 15.27 & 15.51 & 14.12 & 17.13 \\
\hline Mean & --- & $\mathbf{1 3 . 8 4}$ & $\mathbf{1 4 . 3 9}$ & $\mathbf{1 3 . 5 8}$ & $\mathbf{1 6 . 4 2}$ \\
\hline \multirow{2}{*}{$\mathbf{2 1 0}$ days } & $\mathbf{1}$ & 14.63 & 16.35 & 13.00 & 16.12 \\
& $\mathbf{1 0}$ & 16.01 & 16.83 & 14.94 & 16.98 \\
& $\mathbf{2 0}$ & 17.99 & 18.07 & 19.06 & 18.45 \\
\hline Mean & $\mathbf{3 0}$ & 19.94 & 18.46 & 22.02 & 20.13 \\
\hline
\end{tabular}


Top variety had the highest mean values of white sucrose recovery, after 180 and 210 days of harvesting times, while pleno variety recorded the lowest mean values in white sucrose, at most of the harvesting times under open-air storage (Table 3). In the third condition of storage at room temperature Top variety had the highest mean values at 210 days $(23.04 \%)$, while, Kawemira variety recorded the lowest mean values at 195 days (13.95\%) of white sucrose (Table 4). The increase in white sucrose content was higher in late dates than early dates of harvest, probably due to higher temperature at later dates than of earlier dates.

Coverage with foliage prolonged roots deterioration and decreased the losses through a storage period compared to uncovered, open-air roots which recorded the highest loss rate in white sucrose. On the other hand, white sucrose content increased in the storage periods from harvest to 30 days after harvest for all varieties. Roots piles without any cover recorded the highest loss percentage during storage time. In generally, top variety recorded the highest white sucrose content in storage under open-air $(23.04 \%)$ and store room (19.36\%) at 210 days after harvesting, while ceres poly variety recorded the highest white sucrose content $(17.92 \%)$ at 210 days after harvesting under covering storage condition. Under covering and store room storage condition pleno variety recorded the lowest mean values of white sucrose content were 17.14 and $17.39 \%$; respectively at 210 days after harvesting, while Kawemira variety recorded the lowest percentage $(18.57 \%)$ at 210 days after harvesting in open-air condition. Similar results were obtained by Al-Barbari et al. $(2014 \mathrm{a}, \mathrm{b})$ who found that SR was ranged from 14.31 and $15.96 \%$. While, Abd El-Rahman and ElGeddawy (2019) mentioned that the technological characteristics of fresh roots of four varieties of sugar beet which have been grown at different times. White sucrose or sucrose recovery (SR) of four varieties harvested at three periods ranged between 8.76 and $16.35 \%$.

Table (3): Effect of storage period under open-air storage condition on the sugar recovery percentage (white sucrose) of four sugar beet varieties harvested at different times

\begin{tabular}{|c|c|c|c|c|c|}
\hline \multirow{3}{*}{ Harvesting time } & \multirow{3}{*}{$\begin{array}{l}\text { Open-air storage } \\
\text { periods in days }\end{array}$} & \multicolumn{4}{|c|}{ Sugar recovery \% (white sucrose) } \\
\hline & & \multicolumn{4}{|c|}{ Beet varieties } \\
\hline & & Pleno & Top & Kawemira & Ceres poly \\
\hline \multirow{4}{*}{180 days } & 1 & 11.42 & 9.45 & 10.36 & 8.76 \\
\hline & 10 & 12.85 & 15.19 & 13.74 & 14.75 \\
\hline & 20 & 13.68 & 19.33 & 16.56 & 17.40 \\
\hline & 30 & 13.95 & 21.71 & 17.05 & 19.83 \\
\hline Mean & --- & 12.98 & 16.42 & 14.43 & 15.19 \\
\hline \multirow{4}{*}{195 days } & 1 & 12.34 & 13.69 & 12.84 & 14.86 \\
\hline & 10 & 15.51 & 15.14 & 16.37 & 17.22 \\
\hline & 20 & 16.17 & 18.99 & 17.69 & 18.50 \\
\hline & 30 & 18.12 & 19.55 & 22.53 & 18.44 \\
\hline Mean & --- & 15.54 & 16.84 & 17.36 & 17.26 \\
\hline \multirow{4}{*}{210 days } & 1 & 14.63 & 16.35 & 13.00 & 16.12 \\
\hline & 10 & 17.76 & 20.23 & 17.68 & 17.96 \\
\hline & 20 & 21.73 & 26.18 & 21.87 & 24.44 \\
\hline & 30 & 26.72 & 29.39 & 21.71 & 25.12 \\
\hline Mean & --- & 20.21 & 23.04 & 18.57 & 20.91 \\
\hline
\end{tabular}

Sucrose recovery depended on some factors such as sucrose, $\mathrm{K}$ and $\alpha-\mathrm{N}$ content. It has positive correlation with sucrose content and negative correlation with $\mathrm{Na}, \mathrm{K}$ and $\alpha-\mathrm{N}$ content of sugar beet juice. These findings are in agreement with Gomaa (2009) who reported that SR of beet juice ranged from 14.19 to $15.16 \%$ in beet. 
Table (4): Effect of storage period under storage room storage condition on the sugar recovery percentage (white sucrose) of four sugar beet varieties harvested at different times

\begin{tabular}{|c|c|c|c|c|c|}
\hline \multirow{3}{*}{ Harvesting time } & \multirow{3}{*}{$\begin{array}{l}\text { Storage room storage } \\
\text { periods in days }\end{array}$} & \multicolumn{4}{|c|}{ Sugar recovery \% (white sucrose) } \\
\hline & & \multicolumn{4}{|c|}{ Beet varieties } \\
\hline & & Pleno & Top & Kawemira & Ceres poly \\
\hline \multirow{4}{*}{180 days } & 1 & 11.42 & 9.45 & 10.36 & 8.76 \\
\hline & 10 & 11.82 & 12.75 & 12.99 & 13.43 \\
\hline & 20 & 12.50 & 12.75 & 13.75 & 14.78 \\
\hline & 30 & 13.77 & 14.41 & 14.61 & 16.90 \\
\hline Mean & -- & 12.38 & 12.34 & 12.93 & 13.47 \\
\hline \multirow{4}{*}{195 days } & 1 & 12.34 & 13.69 & 12.84 & 14.86 \\
\hline & 10 & 13.84 & 16.24 & 13.14 & 15.68 \\
\hline & 20 & 16.96 & 14.47 & 14.47 & 17.77 \\
\hline & 30 & 17.73 & 17.54 & 15.34 & 17.97 \\
\hline Mean & --- & 15.22 & 15.49 & 13.95 & 16.57 \\
\hline \multirow{4}{*}{210 days } & 1 & 14.63 & 16.35 & 13.00 & 16.12 \\
\hline & 10 & 15.96 & 19.23 & 18.71 & 18.73 \\
\hline & 20 & 19.03 & 19.93 & 22.31 & 19.84 \\
\hline & 30 & 19.94 & 21.90 & 22.77 & 22.32 \\
\hline Mean & --- & 17.39 & 19.36 & 19.20 & 19.26 \\
\hline
\end{tabular}

\section{Sucrose percentage losses in wastes:}

Sucrose loss percentage in wastes of four sugar beet varieties harvested at three periods as influenced by method and period of storage, are presented in Tables (5, 6 and 7). There were differences in sucrose losses percentage in wastes of four sugar beet varieties at all storage conditions. Under covering storage procedure, ceres poly variety recorded the highest mean value $(4.47 \%)$ sucrose loss, followed by top variety $(4.11 \%)$, followed by pleno variety $(3.97 \%)$ at harvesting periods; respectively, while, ceres poly variety recorded lower values almost harvesting dates (Table 5).

Table (5): Effect of storage period under covering storage condition on the sucrose loss percentage in wastes of four sugar beet varieties harvested at different times

\begin{tabular}{|c|c|c|c|c|c|}
\hline \multirow{3}{*}{ Harvesting time } & \multirow{3}{*}{$\begin{array}{l}\text { Covering storage } \\
\text { periods in days }\end{array}$} & \multicolumn{4}{|c|}{ Loss sucrose (\%) } \\
\hline & & \multicolumn{4}{|c|}{ Beet varieties } \\
\hline & & Pleno & Top & Kawemira & Ceres poly \\
\hline \multirow{4}{*}{180 days } & 1 & 3.18 & 3.41 & 3.38 & 3.65 \\
\hline & 10 & 3.75 & 3.81 & 3.64 & 3.81 \\
\hline & 20 & 2.26 & 4.50 & 4.03 & 6.13 \\
\hline & 30 & 4.63 & 4.80 & 4.31 & 4.27 \\
\hline Mean & --- & 3.46 & 4.13 & 3.84 & 4.47 \\
\hline \multirow{4}{*}{195 days } & 1 & 3.66 & 3.69 & 3.47 & 3.17 \\
\hline & 10 & 3.82 & 3.78 & 3.54 & 3.46 \\
\hline & 20 & 4.08 & 4.31 & 3.78 & 3.78 \\
\hline & 30 & 4.23 & 4.64 & 4.19 & 4.00 \\
\hline Mean & --- & 3.95 & 4.11 & 3.75 & 3.63 \\
\hline \multirow{4}{*}{210 days } & 1 & 3.68 & 3.15 & 3.38 & 2.88 \\
\hline & 10 & 3.74 & 3.48 & 3.69 & 3.08 \\
\hline & 20 & 4.17 & 4.14 & 3.85 & 3.55 \\
\hline & 30 & 4.28 & 4.24 & 4.01 & 3.74 \\
\hline Mean & --- & 3.97 & 3.76 & 3.73 & 3.31 \\
\hline
\end{tabular}


Pleno variety was highest mean values were ranged from 4.26 to $4.46 \%$ of sucrose losses in waste at all harvesting times, while, ceres poly variety recorded the lowest mean values were ranged from 3.59 to $4.00 \%$ atall harvesting dates under open-air storage (Table 6). Pleno variety had the highest mean values of sucrose losses in waste at almost harvesting dates, whereas, ceres poly variety recorded the lowest mean values at all harvesting dates when stored in store room. Generally, the percentage of sucrose loss in wastes within the ranged of 2.80 and $3.68 \%$ as reported by Salami and Saadat (2013).

Table (6): Effect of storage period under open-air storage condition on the sucrose loss percentage in wastes of four sugar beet varieties harvested at different times

\begin{tabular}{|c|c|c|c|c|c|}
\hline \multirow{3}{*}{ Harvesting time } & \multirow{3}{*}{$\begin{array}{l}\text { Open-air storage } \\
\text { periods in days }\end{array}$} & \multicolumn{4}{|c|}{ Loss sucrose (\%) } \\
\hline & & \multicolumn{4}{|c|}{ Beet varieties } \\
\hline & & Pleno & Top & Kawemira & Ceres poly \\
\hline \multirow{4}{*}{180 days } & 1 & 3.18 & 3.41 & 3.36 & 3.64 \\
\hline & 10 & 4.46 & 4.12 & 3.92 & 4.20 \\
\hline & 20 & 4.85 & 4.51 & 4.80 & 4.51 \\
\hline & 30 & 5.36 & 5.07 & 5.18 & 4.63 \\
\hline Mean & --- & 4.46 & 4.28 & 4.32 & 4.25 \\
\hline \multirow{4}{*}{195 days } & 1 & 3.66 & 3.39 & 3.47 & 3.14 \\
\hline & 10 & 4.13 & 4.01 & 3.76 & 3.37 \\
\hline & 20 & 4.78 & 4.52 & 4.44 & 4.50 \\
\hline & 30 & 5.18 & 4.76 & 4.97 & 5.00 \\
\hline Mean & --- & 4.44 & 4.17 & 4.16 & 4.00 \\
\hline \multirow{4}{*}{210 days } & 1 & 3.68 & 3.15 & 3.38 & 2.88 \\
\hline & 10 & 4.17 & 3.89 & 3.93 & 3.46 \\
\hline & 20 & 4.42 & 4.64 & 4.28 & 3.91 \\
\hline & 30 & 4.74 & 4.73 & 4.47 & 4.10 \\
\hline Mean & --- & 4.26 & 4.10 & 4.02 & 3.59 \\
\hline
\end{tabular}

Table (7): Effect of storage period under storage room storage condition on sucrose loss percentage in wastes of four sugar beet varieties harvested at different times

\begin{tabular}{|c|c|c|c|c|c|}
\hline \multirow{3}{*}{ Harvesting time } & \multirow{3}{*}{$\begin{array}{l}\text { Storage room storage } \\
\text { periods in days }\end{array}$} & \multicolumn{4}{|c|}{ Loss sucrose (\%) } \\
\hline & & \multicolumn{4}{|c|}{ Beet varieties } \\
\hline & & Pleno & Top & Kawemira & Ceres poly \\
\hline \multirow{4}{*}{180 days } & 1 & 3.18 & 3.31 & 3.36 & 3.64 \\
\hline & 10 & 4.19 & 4.16 & 3.93 & 3.92 \\
\hline & 20 & 5.05 & 4.59 & 4.28 & 4.25 \\
\hline & 30 & 5.43 & 4.81 & 4.89 & 4.45 \\
\hline Mean & --- & 4.47 & 4.22 & 4.12 & 4.07 \\
\hline \multirow{4}{*}{195 days } & 1 & 3.66 & 3.39 & 3.47 & 3.14 \\
\hline & 10 & 4.19 & 3.71 & 3.89 & 3.45 \\
\hline & 20 & 4.57 & 6.63 & 4.03 & 4.14 \\
\hline & 30 & 4.77 & 4.97 & 4.31 & 4.54 \\
\hline Mean & --- & 4.30 & 4.68 & 3.93 & 3.82 \\
\hline \multirow{4}{*}{210 days } & 1 & 3.68 & 3.15 & 3.38 & 2.88 \\
\hline & 10 & 3.99 & 3.72 & 3.80 & 3.22 \\
\hline & 20 & 4.48 & 4.20 & 4.00 & 3.74 \\
\hline & 30 & 4.68 & 4.41 & 4.32 & 3.92 \\
\hline Mean & --- & 4.21 & 3.87 & 3.88 & 3.44 \\
\hline
\end{tabular}


These findings are in agreement with results presented by Gomaa (2009) who reported that the losses of sucrose in wastes were ranged from 3.06 to $4.12 \%$ in sugar beet juice. Similar results were obtained by Abd El-Rahman and El-Geddawy (2019) who found that the Sucrose loss value in wastes of four varieties harvested at three periods ranged between 2.88 and 3.62\%.From data in Tables (5, 6 and 7), it could be said that by decreasing the sucrose loss in wastes, caused an increasing in white sugar production.

Different techniques of beet roots storage showed that the effects on sucrose losses in wastes are varying. Roots storage in open-air (without cover) caused a decrease in white sucrose production compared to those covered with tops. Roots covered with tops have recorded the lowest decrease in sucrose losses in wastes. The results are in agreement with those reported by AlJbawi et al. (2015).

The results showed that under all storage treatment sucrose loss percentage in wastes increased due to prolongation of storage period from 1 to 30 days after harvest. Sugar beet roots stored by foliage covering recorded the lowest values, deterioration under all periods of storage. Generally, storage losses at late harvest dates were lower than those at early harvest dates.

Generally, the presented results of the changes of sucrose losses content during storage under the tested procedures are in agreement with the findings of Hoffmann (2010).

The elevation of sucrose percentage in wastes may be due to the increase of water loss as a result of respiration process of beet roots (Wyse, 1979).

\section{Juice purity:}

The effect of storage condition on the changes of sugar beet juice purity was given in Tables $(8,9$ and
10). The results revealed that the sugar beet juice purity of four sugar beet varieties has increased during stage under the different storage conditions.

Under covering storage procedure (Table 8) top variety recorded the highest mean values were 78.27 and $84.74 \%$ at 180 and 210 days after harvesting; respectively, while, ceres poly variety was $85.37 \%$ at 195 days after harvesting of juice purity, on the other hand, Kawemira variety gave the lowest mean values $(74.82 \%)$, followed by ceres poly variety $(75.34 \%)$, then followed by pleno variety $(80.30 \%)$ at 195,180 and 210 days after harvesting; respectively of juice purity.

In open-air storage procedure (Table 9), top variety recorded the highest mean values of juice purity at most of the harvesting dates, while, ceres poly variety recorded the lowest mean values $(75.13 \%)$ of juice purity, followed by pleno variety $(75.91 \%)$, then followed by Kawemira variety $(79.33 \%)$ at the harvesting dates.

In store room procedure (Table 10), ceres poly variety had the highest mean values $(84.86 \%)$ of juice purity at 195 days after harvesting, as well as, ceres poly variety recorded the lowest mean values $(75.71 \%)$ of juice purity at 180 days of the harvesting dates. Similar results were obtained by Abd El-Rahman and ElGeddawy (2019) who found that the purity of sugar beet juice of four varieties harvested at three periods ranged between 68.13 and $81.58 \%$.

The results showed that under all storage treatments of juice, the purity increased due to prolongation of storage period from 30 days after harvest. Sugar beet roots stored without covering top (open-air) recorded higher values than sugar beet juice purity of those covered with tops.

Table (8): Effect of storage period under covering storage condition on the juice purity percentage of four sugar beet varieties harvested at different times

\begin{tabular}{|c|c|c|c|c|c|}
\hline \multirow{3}{*}{ Harvesting time } & \multirow{3}{*}{$\begin{array}{l}\text { Covering storage } \\
\text { periods in days }\end{array}$} & \multicolumn{4}{|c|}{ Juice purity (\%) } \\
\hline & & \multicolumn{4}{|c|}{ Beet varieties } \\
\hline & & Pleno & Top & Kawemira & Ceres poly \\
\hline \multirow{4}{*}{180 days } & 1 & 76.04 & 74.76 & 75.80 & 68.13 \\
\hline & 10 & 75.97 & 82.87 & 78.80 & 78.28 \\
\hline & 20 & 78.89 & 77.82 & 74.59 & 80.95 \\
\hline & 30 & 80.85 & 77.61 & 75.39 & 74.00 \\
\hline Mean & --- & 77.94 & 78.27 & 76.15 & 75.34 \\
\hline \multirow{4}{*}{195 days } & 1 & 74.76 & 77.63 & 72.16 & 80.71 \\
\hline & 10 & 77.51 & 76.81 & 73.14 & 87.66 \\
\hline & 20 & 80.42 & 81.93 & 76.70 & 88.23 \\
\hline & 30 & 83.37 & 85.38 & 77.26 & 84.86 \\
\hline Mean & --- & 79.02 & 80.44 & 74.82 & 85.37 \\
\hline \multirow{4}{*}{210 days } & 1 & 79.60 & 81.86 & 74.79 & 80.50 \\
\hline & 10 & 80.61 & 83.23 & 79.58 & 82.89 \\
\hline & 20 & 77.75 & 85.05 & 84.53 & 82.39 \\
\hline & 30 & 83.23 & 88.80 & 85.34 & 84.94 \\
\hline Mean & --- & 80.30 & 84.74 & 81.06 & 82.68 \\
\hline
\end{tabular}


Table (9): Effect of storage period under open-air storage condition on the juice purity percentage of four sugar beet varieties harvested at different times

\begin{tabular}{cccccc}
\hline \multirow{3}{*}{ Harvesting time } & \multirow{2}{*}{$\begin{array}{c}\text { Open-air storage } \\
\text { periods in days }\end{array}$} & \multicolumn{4}{c}{ Juice purity (\%) } \\
\cline { 3 - 6 } & & Pleno & Top & Kawemira & Ceres poly \\
\cline { 2 - 6 } & 1 & 76.04 & 74.76 & 75.80 & 68.13 \\
\cline { 2 - 5 } $\mathbf{1 8 0}$ days & 10 & 78.72 & 87.37 & 79.66 & 76.72 \\
& 20 & 77.20 & 93.85 & 80.60 & 76.87 \\
& 30 & 78.81 & 79.46 & 79.11 & 78.81 \\
\hline Mean & --- & $\mathbf{7 7 . 6 9}$ & $\mathbf{8 3 . 8 6}$ & $\mathbf{7 8 . 7 9}$ & $\mathbf{7 5 . 1 3}$ \\
\hline \multirow{2}{*}{$\mathbf{1 9 5}$ days } & 1 & 74.76 & 77.63 & 72.16 & 80.71 \\
& 10 & 80.81 & 82.45 & 81.16 & 84.38 \\
& 20 & 76.18 & 78.36 & 78.75 & 82.73 \\
\hline Mean & 30 & 71.87 & 74.34 & 80.64 & 80.50 \\
\hline \multirow{2}{*}{ 210 days } & --- & $\mathbf{7 5 . 9 1}$ & $\mathbf{7 8 . 2 0}$ & $\mathbf{7 8 . 1 8}$ & $\mathbf{8 2 . 0 8}$ \\
& 1 & 79.60 & 81.58 & 74.79 & 80.50 \\
& 10 & 81.64 & 88.36 & 77.58 & 80.83 \\
\hline Mean & 20 & 81.46 & 82.88 & 79.90 & 85.52 \\
\hline & 30 & 84.79 & 86.59 & 85.04 & 83.96 \\
\hline
\end{tabular}

Table (10): Effect of storage period under storage room storage condition on the juice purity percentage of four sugar beet varieties harvested at different times

\begin{tabular}{cccccc}
\hline \multirow{2}{*}{ Harvesting time } & $\begin{array}{c}\text { Storage room storage } \\
\text { periods in days }\end{array}$ & \multicolumn{4}{c}{ Juice purity (\%) } \\
\cline { 3 - 6 } & & Pleno & Top & Kawemira & Ceres poly \\
\cline { 2 - 6 } & 1 & 76.04 & 74.76 & 78.80 & 68.13 \\
\cline { 2 - 6 } $\mathbf{1 8 0}$ days & 10 & 75.18 & 76.51 & 75.34 & 80.32 \\
& 20 & 80.13 & 79.16 & 76.39 & 73.19 \\
& 30 & 86.09 & 78.46 & 76.17 & 81.18 \\
\hline Mean & --- & $\mathbf{7 9 . 3 6}$ & $\mathbf{7 7 . 2 2}$ & $\mathbf{7 6 . 6 8}$ & $\mathbf{7 5 . 7 1}$ \\
\hline \multirow{2}{*}{$\mathbf{1 9 5}$ days } & 1 & 74.76 & 77.63 & 72.16 & 80.71 \\
& 10 & 74.81 & 82.43 & 73.72 & 81.75 \\
& 20 & 82.80 & 84.03 & 77.46 & 89.06 \\
\hline Mean & 30 & 81.81 & 83.06 & 81.87 & 87.92 \\
\hline \multirow{2}{*}{ 210 days } & --- & $\mathbf{7 8 . 5 5}$ & $\mathbf{8 1 . 7 9}$ & $\mathbf{7 6 . 3 0}$ & $\mathbf{8 4 . 8 6}$ \\
& 1 & 79.60 & 81.58 & 74.79 & 80.60 \\
& 10 & 80.19 & 84.68 & 84.30 & 82.83 \\
\hline Mean & 20 & 80.51 & 82.92 & 87.99 & 82.44 \\
\hline
\end{tabular}

Generally, juice purity percentage was higher indirect open-air than in covering. This was due to the high loss of water in direct open which caused an increase in the concentration of total soluble solids and consequently sucrose percentage. Similar results were obtained by Joshi et al. (2006) and Alfaig et al. (2011) who determined the purity too and they were ranged from 65.483 to 73.030 and 78.59 to $82.45 \%$; respectively at harvest. It can be said that; the main aim of the sugar factory is to separate non-sugar from sugar to improve the beet juice purity to the extent that sugar with $100 \%$ purity is produced. Also, by increasing the purity of beet juice, it would make sugar beet processing much faster and easier. These results were supported by 
Asadi (2007) who mentioned that the purity of beet juice usually ranged between 85 to $88 \%$ in atypical washed beet (beet without tare).

From Tables $(8,9$ and 10) it can be recognized very clearly that the beet quality depends on the condition of beet roots, healthy or injured. So that the beet quality decrease in the case of arising alkaline ( $\mathrm{K}$ and $\mathrm{Na}$ content) and nitrogen content.

\section{CONCLUSION}

From obtained data in this study, it can be concluded that the storage of sugar beet roots in open air was better in case of sugar recovery followed by inroom storage. The purity of sugar beet juice stored in the storage room was relatively higher compared to other treatments.

\section{REFERENCES}

Abd El-Rahman, M. A. M. and M. M. A. El-Geddawy (2019). Chemical and Technological characteristics of fresh roots of four sugar beet varieties harvested at different dates. J. Food Sciences; Suez Canal University, 6(1): 43- 48.

Al-Barbari, F. S., E. G. I. Mohamed, M. A. Abd-ELRahman and S. I. Elsyiad (2014a). Quality of sugar beet in relation to sugar losses in final molasses. The $1^{\text {st }}$ Mans. Inter. Food Conf. November, p171-178.

Al-Barbari, F. S., E. G. I. Mohamed, M. A. Abd-ELRahman and S. I. Elsyiad (2014b). Quality of beet juice and its liquor during beet sugar processing. J. Food and Dairy Sci., Mansoura Univ., 5(6): 367 - 376.

Abou-Salama, A. M. and S. I. El-Syiad (2000). Studies on some sugar beet cultivars under Middle Egypt conditions. I. Response to planting and harvesting dates. Assiut Journal of Agricultural Sciences, 31(1), 137-159.

Alfaig, I. A., K. S. Hassen and A. E. Mohamed (2011). Evaluation of sugar beet parameters burring storage. J. Sci. Tech., 12(02): 1-6.

Al-Jbawi, E., S. Al Geddawi and G. Alesha (2015). Quality changes in sugar beet (Beta vulgaris L.) roots during storage period in piles. International Journal of Environment, 4(4): 77-85.

AOAC (2012). Official Methods of the Analysis of AOAC. International $19^{\text {th }}$ Edition, Published by AOAC International. Maryland 20877- 2417, USA.

Asadi, M. (2007). Beet-Sugar Handbook. John Wiley and Sons, Inc., Hoboken, New Jersey.

Brown, J. D. and O. Lilland (1964). Rapid determination of potassium and sodium by flam photometry. Proc. Amer. Soc. Hort. Sci., 48: 341-316.

Cooke, D. A. and J. E. Scott (2012). The sugar beet crop. Springer Science \& Business Media.

Draycott, A. P. (2006). Sugar beet. Blackwell Publishing Ltd UK. Ch., 16: 409-455.
FAOSTAT (2018). The data set "Sugar beet, production quantity (tons)" for Egypt contains data from the year 1961 until 2018. http://www.fao.org/ faostat/en/\#data/QC.

Fugate, K. and L. Campbell (2009). Postharvest degradation of sugar beet. Book Chapter, 92-94.

Gomaa, S. (2009). Effect of calcium hydroxide and acetic acid on the rat of deterioration and dextran formation during sugar beet storage. M.Sc. Thesis, Sugar Tech. Research Inst., Assiut Univ. Assiut, Egypt.

Hoffmann, C. M. (2010). Root quality of sugarbeet. Sugar Tech, 12(3-4): 276-287.

Joshi, S. S., S. S. Datir, M. W. Pawar and Y. S. Nerkar (2006). Sucrose metabolism in different sugar beet cultivars. Sugar Tech., 8(1): 69-73

Le Docte, A. (1977). Commercial determination of sugar in sugar beet using the socks. Sugar J., 29: 488-492.

Mekdad, A. A. R. (2015). Sugar beet productivity as affected by nitrogen fertilizer and foliar spraying with boron. Intr. J. Current Micro. App. Sci., 4(4): 151-196.

Mustafa, M. E. (2003). Effect of nitrogen and phosphorus fertilizations on the performance of three sugar beet (Beta vulgaris L.) cultivars M. Sci. thesis (Agric), Agronomy Dept. Fac. of Agric. Khartoum Univ. Sudan.

Pačuta, V., I. Černý, M. Rašovský and J. Pulkrábek (2018). Influence of organic fertilizing, mineral fertilizing and waste lime application on molasses-forming substances content, industrial white sugar yield and field white sugar yield of sugar beet. Listy Cukrovarnické a Řepařské, 134: 62-66.

Pačuta, V., M. Rašovský and I. Černý (2017). Influence of weather condition, variety and biopreparations Alga 300 P, K and Alga 600 on molasses components, white sugar content and white sugar yield of sugar beet. Listy Cukrovarnické a Řepařské, 133: 232-236.

Salami, M. and S. Saadat (2013). Study of potassium and nitrogen fertilizer levels on the yield of sugar beet in jolge cultivar. J. Nov. Appl. Sci., 2 (4): 94-100.

Sapronova, A., A. Joshman and V. Loseava (1979). General technology of sugar and sugar substances. Pischevayapromyshennost pub. Moscow, $464 \mathrm{p}$.

Silin, P. M. and N. P. Silina (1977). Chemical control in sugar technology. Food Technol., pub. USSR, pp. 120-126.

Strausbaugh, C. A. and I. Eujayl (2009). Sugar beet cultivar evaluation for storability and rhizomania resistance. Plant Disease, 93(6): 632-635.

Statista (2019). Sugar production worldwide from $2009 / 2010$ to $2018 / 2019$ (in million metric tons) https://www.statista.com/statistics/249679/totalproduction-of-sugar-worldwide/

USDA (2019). Egypt, Sugar Annual, Increasing Sugar Supply on Expanded Beet Production. This report contains assessments of commodity and 
trade issues made by USDA stuff and not necessarily statements of official U.S Government Policy. Date 4/15/2019 GAIN Report Number: EG-19006, p 1-9. https://gain.fas.usda.gov/Recent\%20GAIN\%20P
ublications/Sugar\%20Annual_Cairo_Egypt_418-2017.pdf.

Wyse, R. E. (1979). Root parameters controlling sucrose content and root yield in Sugarbeet. J. Am. Soc. Sugarbeet Technol., 10: 368-385.

\section{تأثير ظروف التخزين على ناتج السكر الأبيض، وفاقد السكر في المخلفات، ونقاوة العصير خلال} صناعة سكر البنجر

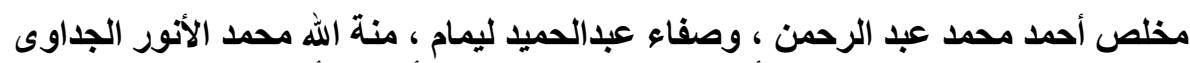

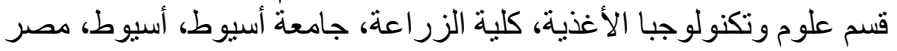

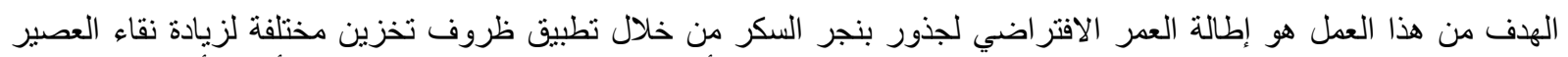

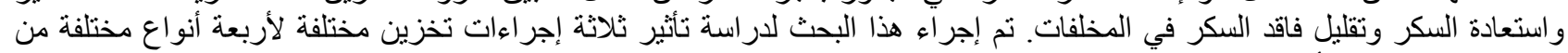

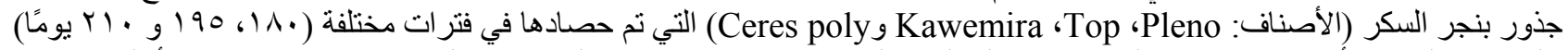

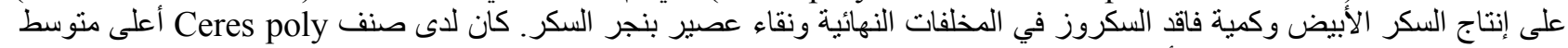

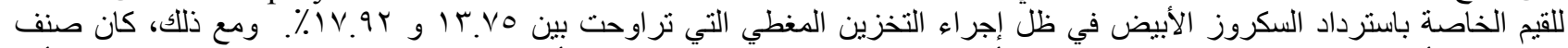

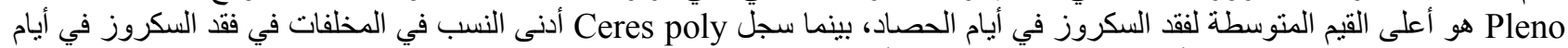

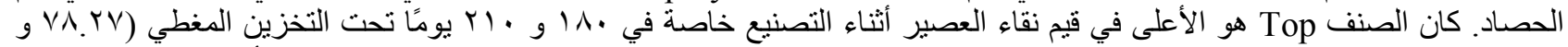

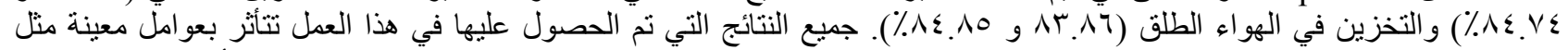

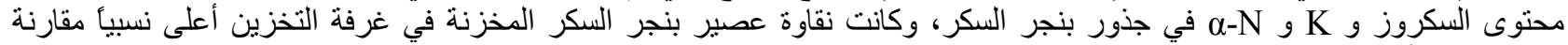
بالمعالجات الأخرى. 